\title{
Evaluation of Endoscopic Thoracic Sympathectomy at T2 and T3 Ganglion Level for Primary Hyperhidrosis
}

\author{
HODA A. YOUSSEF, M.D.; RASHA A. ABD ELGHANY, M.D. and MOHAMMED Sh. ZARAD, M.D. \\ The Department of General Surgery, Faculty of Medicine for Girls, Al Azhar University
}

\begin{abstract}
Background: Primary hyperhidrosis is a benign and idiopathic sympathetic disorder characterized by excessive sweeting with no apparent underlying cause and is aggravated during periods of stress and anxiety with a prevalence of 0.6 $2.8 \%$ of population.

Aim of Study: To compare the effectiveness of thoracic endoscopic sympathectomy either at $\mathrm{T} 2$ and $\mathrm{T} 3$ regarding the patient's satisfaction, compensatory hyperhidrosis and postoperative complications.

Patients and Methods: Forty patients between 13 and 30 years old with primary hyperhidrosis undergoing endoscopic thoracic sympathectomy were divided into two equal groups, the group I: T2 (20 patients) endoscopic thoracic sympathectomy at T2 ganglion level and group II (20 patients) at T3 ganglion level.
\end{abstract}

Results: All patients in both groups had an immediate improvement after the operation with dry hands and $100 \%$ satisfaction. In group I with axillary hyperhidrosis only one patient $(33.3 \%)$ had axillary dryness While in group II: Three patients $(75 \%)$ had axillary dryness. In group I: Two patients (40\%) had planter dryness while in group II: Three patients $(75 \%)$ had planter dryness.

12 patients $(60 \%)$ were complicated by compensatory sweating in group I, and eight patients (40\%) in group II (in back, buttock and thigh), the difference was found statistically non-significant.

Conclusion: Sympathectomy at the T2 or T3 levels provided adequate long-term treatment for palmar hyperhidrosis in terms of initial surgery results, complications, and patient satisfaction. The most frequent complication was compensatory hyperhidrosis. Because of the lower severity of compensatory hyperhidrosis, we prefer the T3 level for treating palmar hyperhidrosis.

Key Words: Palmar hyperhidrosis - Sympathectomy - Compensatory hyperhidrosis.

Correspondence to: Dr. Rasha A. Abd Elghany, E-Mail:rashaabdalaziz@azhar.edu.eg

\section{Introduction}

PRIMARY Hyperhidrosis ( $\mathrm{PH})$ is a benign and idiopathic sympathetic disorder characterized by excessive sweeting with no apparent underlying cause and is aggravated during periods of stress and anxiety with a prevalence of $0.6-2.8 \%$ of population [1-3]. It must be differentiated from secondary hyperhidrosis, which is due to a multiple of stimuli like: From infection, malignancy, medication, anxiety, neurological and endocrine disorders [4]. Although hand sweating has no significant impact on patients' health, and that has significant a negative effect on quality of life, work, educational activities, and social interaction, which will severely impair the patients' emotional wellness [5].

$\mathrm{PH}$ can present at any age, although it tends to affect adolescents and young adults predominantly. Most sweat glands are of the eccrine type, becoming active with puberty, which may explain why hyperhidrosis is rarely seen at an early age and generally becomes evident in the 2 nd and 3 rd decades of life [3].

Hyperhidrosis might also be generalized or localized and there are variants that might also have an effect on the axilla, palms, sole, trunk and face, with axillary $\mathrm{HH}$ being most common followed by palmar $\mathrm{HH}[\mathbf{1 , 6 ]}$.

For many years, traditional conservative treatments like botulinum injections have been proven ineffective and have significant side effects [5]

Before the introduction of Endoscopic thoracic sympathectomy and the advances in videoendoscopic technology, thoracotomy was the standard surgical approach for hyperhidrosis. Endoscopic 
thoracic sympathectomy had replaced open surgery to perform sympathectomy, determining a shorter hospital stay, reduced morbidity rates, less pain, and better cosmetic results for a non-life-risk disease [7].

Endoscopic thoracic sympathectomy is the treatment of choice for palmar hyperhidrosis, as it is a safe, effective, and minimally invasive method. Traditionally, it is used for palmar hyperhidrosis, but latest trials have established accurate clinical success rates for axillary hyperhidrosis as well especially with interruption of upper dorsal sympathetic chain T3 [4]. However, the symptoms may relapse in some patients, and most important side effect is Compensatory Sweating (CS) which can occur in different regions of the body [3] .

The current study aimed to compare the effectiveness of thoracic endoscopic sympathectomy either at T2 and T3 regarding the patient's satisfaction, compensatory hyperhidrosis and post operative complications.

\section{Patients and Methods}

A prospective randomized clinical study has been carried out between December 2017 and December 2019 at the Department of General Surgery, Al-Zahraa University Hospital.

Forty patients between 13 and 30 years old with primary hyperhidrosis suffering from excessive sweating in hands, axilla, and/or sole and scheduled for endoscopic thoracic sympathectomy were included in our study.

The exclusion criteria were patients who had secondary hyperhidrosis, pulmonary disease, previous thoracic surgery, or associated cardiac disease.

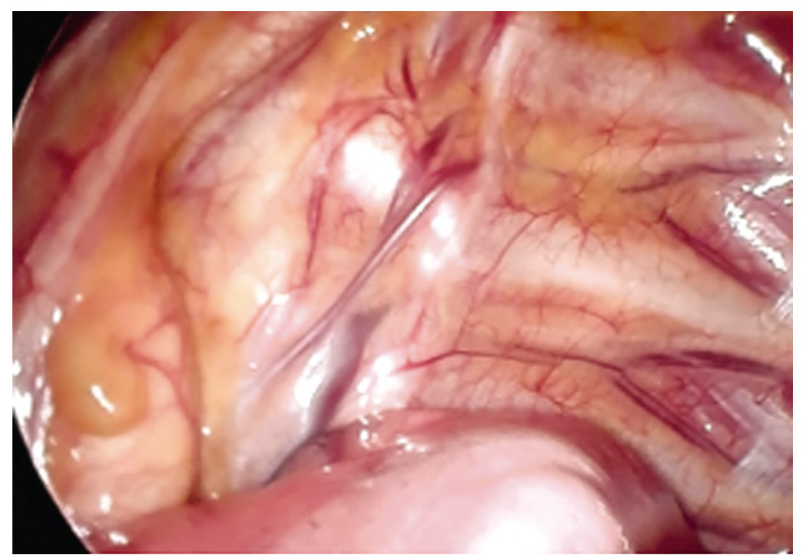

Fig. (1): Sympathetic chain along the side of the ribs.
All included patients were informed about the surgical procedure. Informed consent was taken from all patients or her/his guardian to participate in this study that was bioethically approved by the Bioethics Committee of the faculty. Those patients were randomly allocated using a computerized random number generator into two equal groups, the group I: T2 (20 patients) endoscopic thoracic sympathectomy at $\mathrm{T} 2$ ganglion level and group II (20 patients) at T3 ganglion level.

All patients were clinically diagnosed and all data including age, sex, previous medication, and family history were obtained. All patients had routine blood investigations and chest $\mathrm{X}$-ray.

\section{Operative technique:}

All surgeries were done under general anesthesia with a double-lumen tube. Operations were done in the supine and semi setting position of the patient with the abduction of both arms to expose the axilla with table tilting. $10 \mathrm{~mm}$ port was inserted at the second intercostal space in the midclavicular line with $\mathrm{CO}_{2}$ insufflation and exposing the pleura cavity using 0 camera and identification of sympathetic chain along of the ribs. $5 \mathrm{~mm}$ port was inserted in the midaxillary line at the fifth intercostal space for the diathermy hook. In group I: Cauterization and transection of sympathetic chain at $\mathrm{T} 2$ below the second rib while in group II cauterization and transection of sympathetic chain at T3 below the third rib Figs. $(1,2)$. In both groups, cauterization of the Kuntz's nerve was done to achieve adequate denervation. Inflation of the lung under vision then the same procedure repeated on the other side. All patients had received analgesics and followed-up by a chest X-ray post-operatively and discharged after $24 \mathrm{~h}$ except the complicated cases.

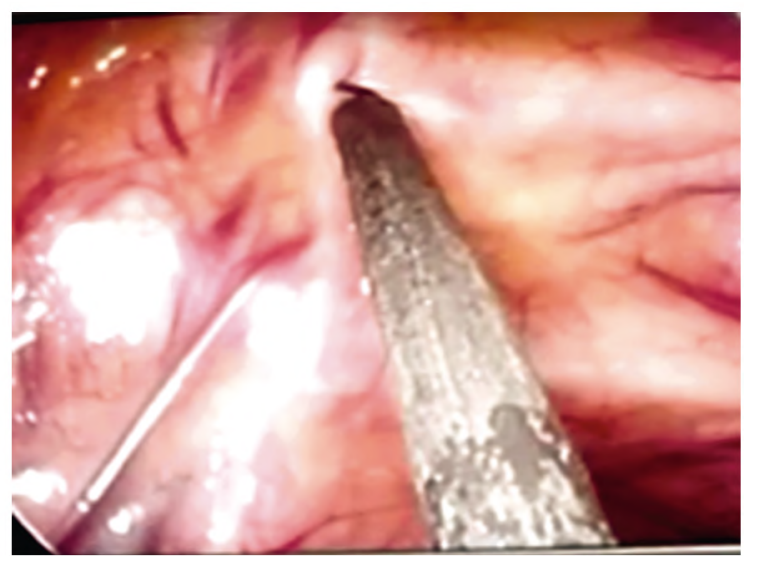

Fig. (2): Cauterization of the sympathetic chain with with Lshaped hook. 


\section{Study endpoints:}

The primary outcomes were patient's satisfaction and compensatory hyperhidrosis.

The secondary outcomes were post-operative complications in the form of pneumothorax, hemothorax, and horner's syndrome.

\section{Statistical analysis:}

Recorded data were analyzed using the statistical package for social sciences, version 20.0 (SPSS Inc., Chicago, Illinois, USA). Quantitative data were expressed as mean \pm Standard Deviation (SD). Qualitative data were expressed as frequency and percentage.

\section{The following tests were done:}

- Independent-samples $t$-test of significance was used when comparing between two means.

- Chi-square $\left(\chi^{2}\right)$ test of significance was used in order to compare proportions between qualitative parameters.

- The confidence interval was set to $95 \%$ and the margin of error accepted was set to $5 \%$. So, the $p$-value was considered significant as the following:

- Probability ( $p$-value).

- $p$-value $<0.05$ was considered significant.

- $p$-value $<0.001$ was considered as highly significant.

- $p$-value $>0.05$ was considered insignificant.

\section{Results}

The present study included 40 patients with primary hyperhidrosis. Those patients were classified into two equal groups, group I (20 patients) endoscopic thoracic sympathectomy at T2 ganglion level and group II (20) patients endoscopic thoracic sympathectomy at $\mathrm{T} 3$ ganglion level.

Patients characteristics of the study groups are listed in (Table 1). In Group I (T2), the age of the patients ranged from 13 to 29 years with a mean of (21.10 \pm 4.59$)$, they included 14 females $(70 \%)$ and 6 males (30\%) with positive family history in three patients (15\%). In Group II (T3), the age of the patients ranged from 15 to 30 years with a mean of (21.95 \pm 4.32$), 16$ females $(80 \%)$ and four males $(20 \%)$ with positive family history in four patients (20\%). Table (1) shows no statistically significant difference between groups according to demographic data.
Table (1): Comparison between group I: T2 and group II: T3 according to demographic data.

\begin{tabular}{|c|c|c|c|c|c|}
\hline $\begin{array}{l}\text { Demographic } \\
\text { data }\end{array}$ & $\begin{array}{c}\text { Group I: } \\
\text { T2 } \\
(n=20)\end{array}$ & $\begin{array}{c}\text { Group II: } \\
\text { T3 } \\
(n=20)\end{array}$ & $\begin{array}{l}\text { Total } \\
(n=40)\end{array}$ & $\chi^{2 \#}$ & $\begin{array}{c}p- \\
\text { value }\end{array}$ \\
\hline \multicolumn{6}{|l|}{ Age (years): } \\
\hline Mean $\pm S D$ & $21.10 \pm 4.59$ & $21.95 \pm 4.32$ & $21.53 \pm 4.42$ & 0.364 & 0.550 \\
\hline Range & $13-29$ & $15-30$ & $13-30$ & & \\
\hline \multicolumn{6}{|l|}{ Gender: } \\
\hline Female & $14(70.0 \%)$ & $16(80.0 \%)$ & $30(75.0 \%)$ & $0.533 \#$ & 0.465 \\
\hline Male & $6 \quad(30.0 \%)$ & $4 \quad(20.0 \%)$ & $10(25.0 \%)$ & & \\
\hline \multicolumn{6}{|l|}{ Family history: } \\
\hline Negative & $17(85.0 \%)$ & $16(80.0 \%)$ & $33(82.5 \%)$ & $0.173 \#$ & 0.677 \\
\hline Positive & $3 \quad(15.0 \%)$ & $4 \quad(20.0 \%)$ & $7 \quad(17.5 \%)$ & & \\
\hline
\end{tabular}

$t_{2}$ : Independent Sample $t$-test.

$\# \chi^{2}:$ Chi-square test $p$-value $>0.05$ NS.

\section{Pre-operative diagnosis:}

In Group I (T2), 13 patients (65\%) had palmer hyperhidrosis only, two patients $(10 \%)$ were presented with palmar + axillary hyperhidrosis, four patients were presented with Palmar \& Plantar and one patient $(5 \%)$ had palmer \& axillary \& planter hyperhidrosis. In Group II (T3), Palmer hyperhidrosis only was present in 12 patients $(60 \%)$, palmar + axillary hyperhidrosis in four patients (20\%), Palmar \& Plantar in four patients and both palmer \& axillary \& planter in zero patients $(0 \%)$. Table (2) show no statistically significant differences between both groups according to pre-operative variables.

Table (2): Comparison between group I: T2 and group II: T3 according to pre-operative diagnosis.

\begin{tabular}{|c|c|c|c|c|c|}
\hline $\begin{array}{l}\text { Pre-operative } \\
\text { diagnosis }\end{array}$ & $\begin{array}{c}\text { Group I: } \\
\text { T2 } \\
(n=20)\end{array}$ & $\begin{array}{c}\text { Group II: } \\
\text { T3 } \\
(n=20)\end{array}$ & $\begin{array}{c}\text { Total } \\
(\mathrm{n}=40)\end{array}$ & $x^{2}$ & $\begin{array}{c}p- \\
\text { value }\end{array}$ \\
\hline - Palmar & $13(65.0 \%)$ & $12(60.0 \%)$ & $25(62.5 \%)$ & 1.707 & 0.635 \\
\hline $\begin{array}{c}\text { Palmar + } \\
\text { Axillary }\end{array}$ & $2(10.0 \%)$ & $4(20.0 \%)$ & $6(15.0 \%)$ & & \\
\hline $\begin{array}{l}\text { - Palmar + } \\
\text { Plantar }\end{array}$ & $4(20.0 \%)$ & $4(20.0 \%)$ & $8(20.0 \%)$ & & \\
\hline $\begin{array}{l}\text { - Palmar + } \\
\text { Axillary + } \\
\text { Plantar }\end{array}$ & $1(5.0 \%)$ & $0(0.0 \%)$ & $1(2.5 \%)$ & & \\
\hline
\end{tabular}

$\chi^{2}$ : Chi-square test; $p$-value $>0.05$ NS.

\section{Post-operative complications:}

In group I: No intraoperative bleeding from intercostal veins occurred, while in group II occurred in one patient (5\%), all were all controlled by diathermy. In group I: One patient $(5 \%)$ had a unilateral pneumothorax after surgery and need insertion of chest tube and the tube removed after three days with no residual pneumothorax; while no patients in group II developed post-operative pneumothorax, however the difference was found to be statistically non-significant (Table 3). No 
operative mortality neither conversion to open thoracotomy were recorded. There was no major haemothorax, chylothorax, atelectasis, or horner's syndrome in both groups.

Table (3): Comparison between group I: T2 and group II: T3 according to post-operative complications.

\begin{tabular}{lccccc}
\hline $\begin{array}{l}\text { Post-operative } \\
\text { complications }\end{array}$ & $\begin{array}{c}\text { Group I: } \\
\mathrm{T} 2 \\
(\mathrm{n}=20)\end{array}$ & $\begin{array}{c}\text { Group II: } \\
\mathrm{T} 3 \\
(\mathrm{n}=20)\end{array}$ & $\begin{array}{c}\text { Total } \\
(\mathrm{n}=40)\end{array}$ & $\chi^{2}$ & $\begin{array}{c}p \text { - } \\
\text { value }\end{array}$ \\
\hline - Pneumothorax & $1(5.0 \%)$ & $0(0.0 \%)$ & $1(2.5 \%)$ & 1.026 & 0.311 \\
- Hemothorax & $0(0.0 \%)$ & $1(5.0 \%)$ & $1(2.5 \%)$ & 1.026 & 0.311 \\
- Chylothorax & $0(0.0 \%)$ & $0(0.0 \%)$ & $0(0.0 \%)$ & 0.000 & 1.000 \\
- Atelectasis & $0(0.0 \%)$ & $0(0.0 \%)$ & $0(0.0 \%)$ & 0.000 & 1.000 \\
- Horner's & $0(0.0 \%)$ & $0(0.0 \%)$ & $0(0.0 \%)$ & 0.000 & 1.000 \\
$\quad$ syndrome & $0(0.0 \%)$ & $0(0.0 \%)$ & $0(0.0 \%)$ & 0.000 & 1.000 \\
\hline Mortality & $0(0.000$
\end{tabular}

$\chi^{2}$ : Chi-square test; $p$-value $>0.05$ NS.

\section{Follow-up data:}

All patients in both groups had an immediate improvement after the operation with dry hands and $100 \%$ satisfaction. In group I with axillary hyperhidrosis only one patient (33.3\%) had axillary dryness while in group II: Three patients (75\%) had axillary dryness. In group I: Two patients $(40 \%)$ had planter dryness while in group II: Three patients $(75 \%)$ had planter dryness.

12 patients $(60 \%)$ were complicated by compensatory sweating in group I, and eight patients $(40 \%)$ in group II (in back, buttock and thigh), the difference was found statistically non-significant (Table 4).

Complete follow-up information was obtained from 40 patients after one, 6, 12 months at outpatient clinic by clinical assessment or by telephone.

Table (4): Comparison between group I: T2 and group II: T3 according to outcome.

\begin{tabular}{|c|c|c|c|c|c|}
\hline Outcome & $\begin{array}{c}\text { Group I: } \\
\text { T2 } \\
(n=20)\end{array}$ & $\begin{array}{c}\text { Group II: } \\
\text { T3 } \\
(n=20)\end{array}$ & $\begin{array}{l}\text { Total } \\
(\mathrm{n}=40)\end{array}$ & $x^{2}$ & $\begin{array}{c}p- \\
\text { value }\end{array}$ \\
\hline $\begin{array}{l}\text { - Satisfaction } \\
\text { (palmar) }\end{array}$ & $\begin{array}{l}20 \\
(100.0 \%)\end{array}$ & $\begin{array}{l}20 \\
(100.0 \%)\end{array}$ & $\begin{array}{l}40 \\
(100.0 \%)\end{array}$ & 0.000 & 1.000 \\
\hline $\begin{array}{l}\text { - Satisfaction } \\
\text { (axillary) }\end{array}$ & 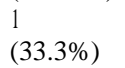 & $3(75 \%)$ & $4(57.1 \%)$ & & \\
\hline $\begin{array}{l}\text { - Satisfaction } \\
\text { (plantar) }\end{array}$ & $2(40 \%)$ & $3(75 \%)$ & $5(55.5 \%)$ & & \\
\hline $\begin{array}{l}\text { - Compensatory } \\
\text { hyperhidrosis }\end{array}$ & $\begin{array}{l}12 \\
(60.0 \%)\end{array}$ & $\begin{array}{l}8 \\
(40.0 \%)\end{array}$ & $20(50 \%)$ & 0.229 & 0.633 \\
\hline
\end{tabular}

$\chi^{2}$ : Chi-square test; $p$-value $>0.05$ NS.

Table (5): Compensatory hyperhidrosis follow-up.

\begin{tabular}{lccc}
\hline Compensatory hyperhidrosis & 1 month & 6 months & 1 year \\
\hline Group I: T2 $(\mathrm{n}=20)$ & $12(60.0 \%)$ & $8(40 \%)$ & $3(15 \%)$ \\
Group II: T3 $(\mathrm{n}=20)$ & $8(40.0 \%)$ & $4(20 \%)$ & $2(10 \%)$ \\
\hline
\end{tabular}

\section{Discussion}

Sweating is mediated by the sympathetic nervous system. The second thoracic ganglion is considered to be the key ganglion for sympathetic denervation of the upper extremity, and interruption of $\mathrm{T} 2$ or $\mathrm{T} 3$ are thus the main sympathetic procedure performed by many surgeons. The reported methodology for ETS is currently confusing, and ETS can be achieved by various methods, such as sympathectomy, sympathicotomy, and ganglionectomy by cauterization, scissor resection, or clamping block [8]

Although there is no evidence for any difference in the prevalence of palmar hyperhidrosis between the sexes, women usually seek treatment more frequently and therefore end up undergoing sympathectomy more often and the patients were also young, with a mean age of $23.4 \pm 5.3$ years (T2) and 23.2 \pm 6.5 years (T3) [9]. In this study in group I female $(70 \%)$ and in group II $(80 \%)$ and range of age was (13-29) in group I (15-30) group II respectively.

Ro et al., had found (65\%) positive family history in their study [10]. In this study positive family history was found $(15.0 \%)$ in group I and $(20.0 \%)$ group II.

Horner's syndrome has become a rare complication because the advanced technique, and it occurred in cases of indirect lesion of the stellate ganglion (T1) due to heat diffusion or excessive traction of the chain. Yazbek et al., had recorded only one case of transient Horner's syndrome in a patient in the T3 group who presented adherent tissue that needed to be detached from one of the lungs [9]. In this study there were no cases of Horner's syndrome.

Bryant and Cerfolio, had observed a radiographic pneumothorax in $67 \%$ of the patients immediately postoperatively and only one patient required a chest tube [11].

In this study only one case of pneumothorax in group I and was treated with chest tube.

Ong et al., had reported overall satisfaction rate of $(72.7 \%)$ and a higher rate of $\mathrm{CH}(91 \%)$ than reported usual rate of around 60\% [12].

Aoki et al., had reported post-operative compensatory sweating in all patients of both groups which decrease their patient satisfaction [13].

Sugimura et al., had reported $96 \%$ of patients with excellent satisfaction for palmar $\mathrm{HH}$ reporting 
substantial improvement and ETS was also highly successful in controlling the symptoms of facial blushing/sweating and axillary $\mathrm{HH}$ with success rates of 89 and $94 \%$, respectively [14].

Yazbek et al., had reportad one month after the operation, compensatory hyperhidrosis in 26 patients in the T2 group (86.66\%) and in 27 in the T3 group (90\%). Six months after the operation, all patients in the T2 group had some degree of compensatory hyperhidrosis and only one patient in the T3 group did not present it (96.6\%). Twenty months after the operation, all patients in both groups presented some degree of compensatory hyperhidrosis [9].

In our study all patient in both groups were satisfied for palmar hyperhidrosis while axillary and plantar hyperhidrosis satisfaction were $(33.3 \%)$ $(40 \%)$ in group I and $(75 \%)(75 \%)$ in group II respectively.

In this study compensatory hyperhidrosis was $(60.0 \%)$ in group I and $(40.0 \%)$ in group II after one month post-operative and six months after the operation was (40\%) in group I and $(20 \%)$ in group II. One year follow-up only three $(15 \%)$ cases in group I and two (10\%) cases in group II of compensatory hyperhidrosis.

The sites of compensatory hyperhidrosis were different regions of the body, including the abdomen, back, gluteal region and thighs. The most frequent regions were between locations on the abdomen and back. The preferential location was similar between the groups.

\section{Conclusion:}

Sympathectomy at the T2 or T3 levels provided adequate long-term treatment for palmar hyperhidrosis in terms of initial surgery results, complications, and patient satisfaction. The most frequent complication was compensatory hyperhidrosis. Because of the lower severity of compensatory hyperhidrosis, we prefer the T3 level for treating palmar hyperhidrosis.

\section{References}

1- GIBBONS J.P., NUGENT E., O'DONOHOE N., MAHER B., EGAN B., FEELEY M., et al.: Experience with botulinum toxin therapy for axillary hyperhidrosis and comparison to modelled data for endoscopic thoracic sympathectomy - A quality of life and cost effectiveness analysis. Surgeon [Internet], 14 (5): 260-4. Available from: http://dx.doi.org/10.1016/j.surge.2015.05.002, 2016.

2- ZHANG W., YU D., WEI Y., XU J. and ZHANG X.: A systematic review and meta-analysis of $\mathrm{T} 2, \mathrm{~T} 3$ or $\mathrm{T} 4$, to evaluate the best denervation level for palmar hyperhidrosis. Sci Rep [Internet], Dec. 9; 7 (1): 129. Available from: http://dx.doi.org/10.1038/s41598-017-00169-w, 2017.

3- TURKYILMAZ A., KARAPOLAT S., SEYIS K.N. and TEKINBAS C.: Comparison of T2 and T3 sympathectomy for compensatory sweating on palmar hyperhidrosis. Med. (United States), 96 (16): 1-4, 2017.

4- VORKAMP T., FOO F.J., KHAN S., SCHMITTO J.D. and WILSON P.: Hyperhidrosis: Evolving concepts and a comprehensive review. Surgeon [Internet], 8 (5): 287 92. Available from: http://dx.doi.org/10.1016/j.surge.2010 $06.002,2010$

5- HUANG L., JIANG H., WEI D., XUE Q., DING Q. and HU R.: A comparative study of thoracoscopic sympathectomy for the treatment of hand sweating. J. Thorac. Dis. [Internet], Aug., 11 (8): 3336-40. Available from: http:// . itd.amegroups.com/article/view/31034/22060, 2019.

6- STASHAK A.B. and BREWER J.D.: Management of hyperhidrosis. Clin. Cosmet. Investig. Dermatol., 7: 28599, 2014.

7- KARMOTA A.G., ABOOLLO M.F., HAFEZ B.A., SHAKER A.A. and GHONEIM B.: Prospective randomized study comparing Video assisted thoracoscopic surgery (VATS) resection versus cautery for treatment of primary hyperhydrosis. J. Egypt Soc. Cardio-Thoracic Surg. [Internet], Dec., 26 (4): 318-23. Available from: https://doi.org/10.1016/j.jescts.2018.11.005, 2018.

8- SANG H.W., LI G.L., XIONG P., ZHU M.C. and ZHU M.: Optimal targeting of sympathetic chain levels for treatment of palmar hyperhidrosis: An updated systematic review. Surg. Endosc., 31 (11): 4357-69, 2017.

9- YAZBEK G., WOLOSKER N., KAUFFMAN P., CAMPOS J.R.M. De, PUECH-LEÃO P. and JATENE F.B.: Twenty months of evolution following sympathectomy on patients with palmar hyperhidrosis: Sympathectomy at the T3 level is better than at the T2 level. Clinics [Internet], 64 (8): 743-9. Available from: http://www. scielo.br/scielo.php?script $=$ sci arttext\&pid $=$ S1807$59322009000800006 \& \operatorname{lng}=$ en\&nrm=iso\&tlng=en, 2009.

10- RO K.M., CANTOR R.M., LANGE K.L. and AHN S.S.: Palmar hyperhidrosis: Evidence of genetic transmission. J. Vasc. Surg., 35 (2): 382-6, 2002.

11- BRYANT A.S. and CERFOLIO R.J.: Satisfaction and compensatory hyperhidrosis rates 5 years and longer after video-assisted thoracoscopic sympathotomy for hyperhidrosis. J. Thorac. Cardiovasc. Surg. [Internet], 147 (4): 1160-3. e1. Available from: http://dx.doi.org/10.1016/ j.jtcvs.2013.12.016, 2014.

12- ONG W., LEE A., TAN W.B. and LOMANTO D.: Longterm results of a randomized controlled trial of $\mathrm{T} 2$ versus T2-T3 ablation in endoscopic thoracic sympathectomy for palmar hyperhidrosis. Surg. Endosc., 30 (3): 121925, 2016.

13- AOKI H., SAKAI T., MURATA H. and SUMIKAWA K.: Extent of sympathectomy affects post-operative compensatory sweating and satisfaction in patients with palmar hyperhidrosis. J. Anesth., 28 (2): 210-3, 2014. 
14- SUGIMURA H., SPRATT E.H., COMPEAU C.G., KAT-

TAIL D. and SHARGALL Y.: Thoracoscopic sympathetic clipping for hyperhidrosis: Long-term results and revers- ibility. J. Thorac. Cardiovasc. Surg. [Internet], 137 (6):

1370-8. Available from: http://dx.doi.org/10.1016/ j.jtcvs.2009.01.008, 2009.

\section{تقييم قطع العصب السمبساوى بالمنظار

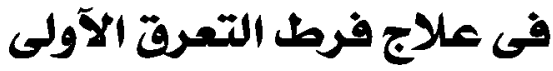 \\ عند الفقرة العصبية الثانية آو الثالثة الثمرة}

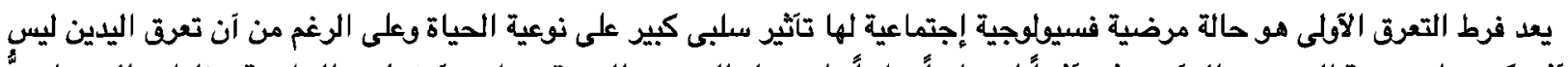

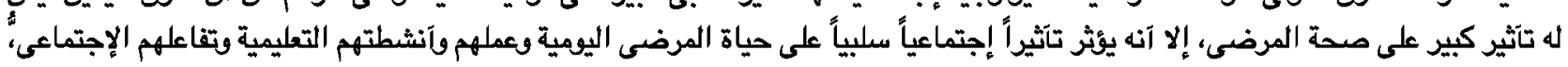

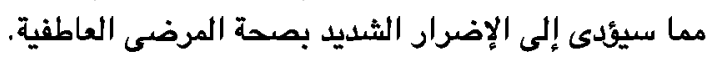

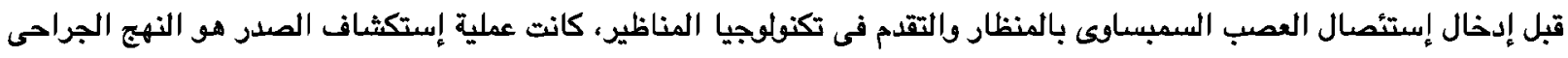

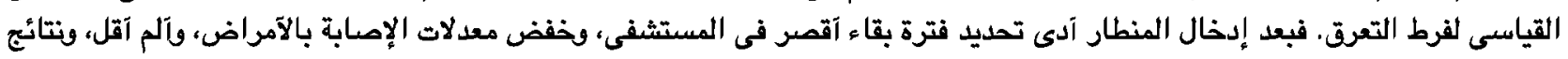
تجميلية آفضل المرض غير خطر على الحياة.

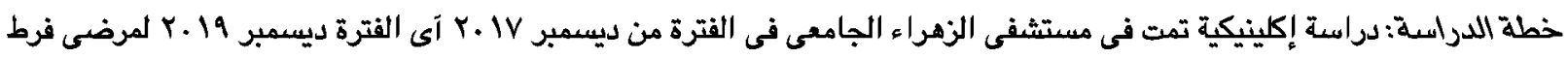
التعرق الآولى.

ما تم إجراؤه: تم إشراك • ع مريض من مرضى فرط التعرق الآولى وتم تقسيمهم إلى مجموعتين متساويتين.

المجموعة الآو لى (·r) تم قطع العصب السمبساوى عند الفقرة العصبية الثانية عن طريق منظار التجويف الصدرى والمجموعة الثانية

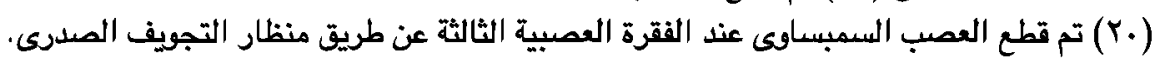

المدخلات: المرضى بين (rآ- بآ) عام والذين يعانون من فرط التعرق الآولى باليد آو الإبط آو القدم والتى تئثر على حياتهم اليومية ويرغبون فى إجراء عملية قطع العصب السمبساوى.

وتم إستبعاد المرضى الذين يعانون من فرط التعرق الثانوى آو مرضى القلب آو الصدر. وبعد إجراء العملية تم سئال المريض عن من مدىى

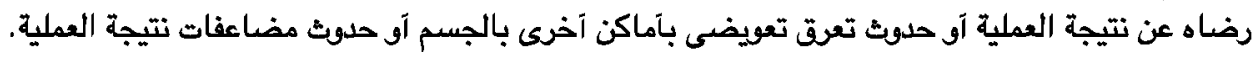

